University of Wollongong

Research Online

Faculty of Science - Papers (Archive)

Faculty of Science, Medicine and Health

September 2004

\title{
Austrochlamys heardensis (Fleming, 1957) (Bivalvia: Pectinidae) from Central Kerguelen Plateau, Indian Ocean: palaeontology and possible tectonic significance
}

P. G. Quilty

University of Tasmania

C. V. Murray-Wallace

University of Wollongong, cwallace@uow.edu.au

J. M. Whitehead

Universtity of Tasmania

Follow this and additional works at: https://ro.uow.edu.au/scipapers

Part of the Life Sciences Commons, Physical Sciences and Mathematics Commons, and the Social and Behavioral Sciences Commons

\section{Recommended Citation}

Quilty, P. G.; Murray-Wallace, C. V.; and Whitehead, J. M.: Austrochlamys heardensis (Fleming, 1957) (Bivalvia: Pectinidae) from Central Kerguelen Plateau, Indian Ocean: palaeontology and possible tectonic significance 2004.

https://ro.uow.edu.au/scipapers/52

Research Online is the open access institutional repository for the University of Wollongong. For further information contact the UOW Library: research-pubs@uow.edu.au 


\title{
Austrochlamys heardensis (Fleming, 1957) (Bivalvia: Pectinidae) from Central Kerguelen Plateau, Indian Ocean: palaeontology and possible tectonic significance
}

\author{
Abstract \\ Austrochlamys heardensis (Fleming) is recorded from a boulder of Late Pliocene (3.62-2.5 Ma) \\ volcaniclastic sandstone dredged $70 \mathrm{~km}$ east-north-east of Heard Island, the third record of the species. \\ The collection is much larger than the original described by Fleming and includes left valves which are \\ described for the first time. The species is compared with A. anderssoni (Hennig) from Cockburn Island \\ and 'Chlamys' mawsoni Fletcher from Îles Kerguelen. The source rock accumulated in fully marine, highly \\ current-affected conditions. The collection is dominated by right valves, possibly because left valves are \\ more susceptible to breakage and the effects of current winnowing. The locality may have subsided some \\ $500 \mathrm{~m}$ since deposition. It lies immediately north of a straight, north-east-south-west trending lineament \\ which may mark a major tectonic feature with left-lateral displacement of approximately $50 \mathrm{~km}$, and \\ provides a natural boundary within the Central Province of Kerguelen Plateau.

\section{Keywords} \\ amino acid dating, bivalve, diatoms, Neogene, Pectinidae, tectonics \\ Disciplines \\ Life Sciences | Physical Sciences and Mathematics | Social and Behavioral Sciences

\section{Publication Details} \\ This article was originally published as: Quilty, PG, Murray-Wallace, CV \& Whitehead, JM, Austrochlamys \\ heardensis (Fleming, 1957) (Bivalvia: Pectinidae) from Central Kerguelen Plateau, Indian Ocean: \\ palaeontology and possible tectonic significance, Antarctic Science, 2004, 16(3), 329-338. Copyright 2004 \\ Cambridge University Press. Journal information can be found here.
}




\title{
Austrochlamys heardensis (Fleming, 1957) (Bivalvia: Pectinidae) from Central Kerguelen Plateau, Indian Ocean: palaeontology and possible tectonic significance
}

\author{
PATRICK G. QUILTY', COLIN V. MURRAY-WALLACE ${ }^{2}$ and JASON M. WHITEHEAD ${ }^{3}$ \\ ${ }^{1}$ School of Earth Sciences, University of Tasmania, Private Box 79, Hobart, TAS 7001, Australia \\ P.Quilty@utas.edu.au \\ ${ }^{2}$ School of Earth and Environmental Sciences, University of Wollongong, NSW 2522, Australia \\ ${ }^{3}$ Institute of Antarctic and Southern Ocean Studies (IASOS), University of Tasmania, Private Bag 77, Hobart, TAS 7001, Australia
}

\begin{abstract}
Austrochlamys heardensis (Fleming) is recorded from a boulder of Late Pliocene (3.62-2.5 Ma) volcaniclastic sandstone dredged $70 \mathrm{~km}$ east-north-east of Heard Island, the third record of the species. The collection is much larger than the original described by Fleming and includes left valves which are described for the first time. The species is compared with A. anderssoni (Hennig) from Cockburn Island and 'Chlamys' mawsoni Fletcher from Îles Kerguelen. The source rock accumulated in fully marine, highly current-affected conditions. The collection is dominated by right valves, possibly because left valves are more susceptible to breakage and the effects of current winnowing. The locality may have subsided some $500 \mathrm{~m}$ since deposition. It lies immediately north of a straight, north-east-south-west trending lineament which may mark a major tectonic feature with left-lateral displacement of approximately $50 \mathrm{~km}$, and provides a natural boundary within the Central Province of Kerguelen Plateau.
\end{abstract}

Received 15 September 2003, accepted 26 April 2004

Key words: amino acid dating, bivalve, diatoms, Neogene, Pectinidae, tectonics

\section{Introduction}

Little is known from fossils of the evolution of Antarctic and sub-Antarctic macrofaunas particularly during the Cenozoic, since Antarctica entered its modern glaciated phase. Much remains to be done to clarify knowledge of many species that have been recovered and to place them into an evolving context. Much has been achieved in recent years in unravelling the history as it relates particularly to one family of bivalve - the Pectinidae.

Fleming (1957) described Austrochlamys heardensis (as Chlamys (Zygochlamys) heardensis) from '... a large boulder of breccia, approximately $3 \mathrm{ft}$. in diameter, lying near the foot of scree slopes, about $5 \mathrm{ft}$. above sea level, near the western end of West Bay, south-west coast of Laurens Peninsula, Heard Island' (L.P. on Fig. 1). His material had been collected in 1953 by $\mathrm{Mr}$ (later Dr) J. Brooks. Despite a search in 1954 for the fossiliferous horizon by Mr B.H. Stinear, the source of the sample has not been found. Lithology and location show that it is from the Drygalski Formation, the dominant, roughly horizontal, $300-350 \mathrm{~m}$ thick unit that is prominent around Heard Island and forms the foundation on which the active volcano Big Ben sits (Quilty \& Wheller 2000, Quilty in press). Fleming compared the new species with other species known from the Southern Hemisphere, commenting particularly on the similarity with $A$. anderssoni (Hennig) from the Pliocene of Cockburn Island, Antarctic Peninsula. He also indicated that it differs markedly from the geographically closest described species, the 'Upper Tertiary' 'Chlamys' mawsoni Fletcher, from Kerguelen Island. Fleming's sample included several specimens but only of right valves.

A second sample containing this species was recovered from Corinth Head $53^{\circ} 01^{\prime} \mathrm{S} ; 7^{\circ} 25^{\prime} \mathrm{E}$ ), Heard Island (Fig. 2) by R.S. Cohen and D. Lawton in 1969 and is lodged with the National Museum of Natural History, Washington (Catalogue No. USGS 25002). It is accompanied by a form indistinguishable from infaunal Laternula elliptica (King \& Broderip) implying a very shallow-water environment of deposition (Jonkers 2003).

On 29 February 2000, FV Austral Champion accidentally trawled a block of lithified sediment from $70 \mathrm{~km}$ east-northeast of Heard Island at $52^{\circ} 55.59^{\prime} \mathrm{S}, 74^{\circ} 34.58^{\prime} \mathrm{E}$, in $579 \mathrm{~m}$ water depth. It contains hundreds of specimens of A. heardensis.

This paper redescribes Austrochlamys heardensis including its left valve, compares $A$. heardensis with A. anderssoni and 'Chlamys' mawsoni, provides an age estimate for the samples, speculates on causes of an apparent preponderance of right valves, comments on environment of deposition, and suggests that the area has subsided considerably since deposition. The site lies on the south-facing slope of a major north-east-south-west trending straight feature. Its possible tectonic significance is explored.

The locality lies on Kerguelen Plateau which has been subdivided in a variety of ways. Schlich \& Wise (1992) 


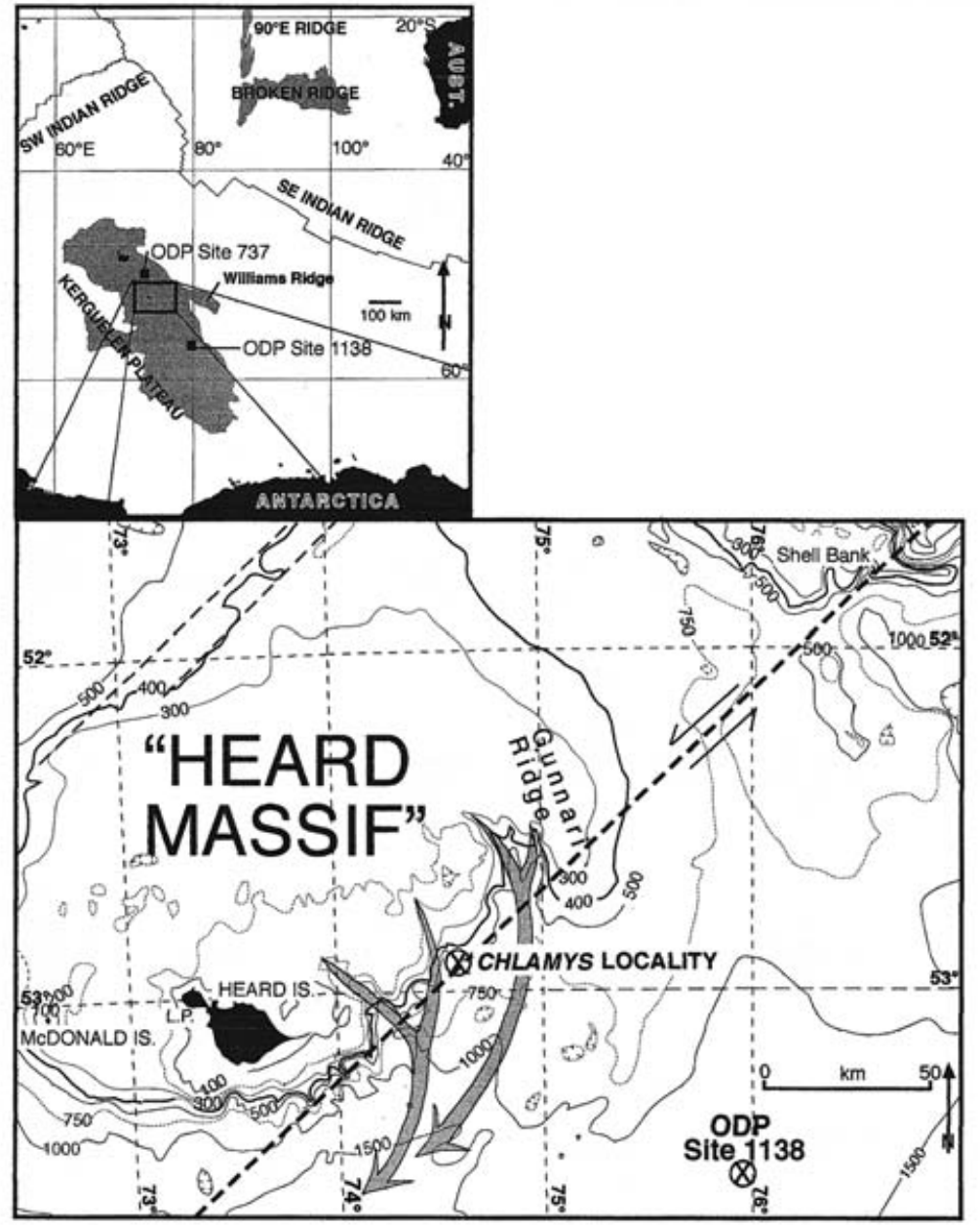

Fig. 1. Locality map to show Heard Island, the source of the new specimens of $A$. heardensis, ODP Site 1138, and NE-SW scarp south of Heard Island. Arrows indicate the suggested sense of movement on the fault scarp (heavy dashed line). L.P. $=$ Laurens Peninsula. $400 \mathrm{~m}$ contour highlighted for emphasis. (After Australian Antarctic Division 1995). Broad shaded arrows refer to direction of sediment transport along submarine canyons. recognized Northern and Southern Kerguelen Plateau, the boundary coinciding closely with the lineament described below. Coffin et al. (2000) used a three-fold division into Northern, Central and Southern Kerguelen Plateau, following Houtz et al. (1977), with the scarp lying in the centre of the Central province. Borissova et al. (2002) employed the threefold subdivision into Northern, Central and Southern Kerguelen Plateau but subdivided each further, and named nine Provinces, one of which is the Central Kerguelen Province, essentially the Central Kerguelen Plateau of Coffin et al. (2000), but with Williams Ridge excluded and identified as a separate province. The Central Kerguelen Province contains the Kerguelen-Heard Basin.

The locality is now at $579 \mathrm{~m}$ below sea level but accumulated in much shallower water, suggesting that there has been post-depositional subsidence (or slumping) of over $500 \mathrm{~m}$. If the sediment was deposited during the Late Pliocene this represents a subsidence of about 160-200 m per million years.

It is highly unlikely that the specimen is ex situ. Ice-rafted debris in the region is dominantly of continental rock derived from mainland Antarctica; this specimen is dominated by basalt clasts, and the species is one known locally.

\section{Material and methods}

The trawled rock is approximately $100 \times 60 \times 40 \mathrm{~cm}$. It contains many specimens of Austrochlamys heardensis,

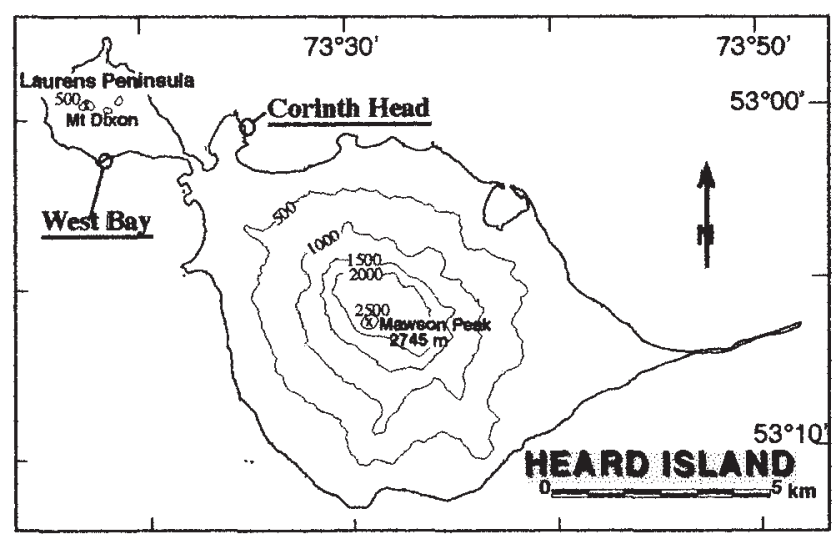

Fig. 2. Localities (underlined) on Heard Island from which $A$. heardensis has been recovered. 


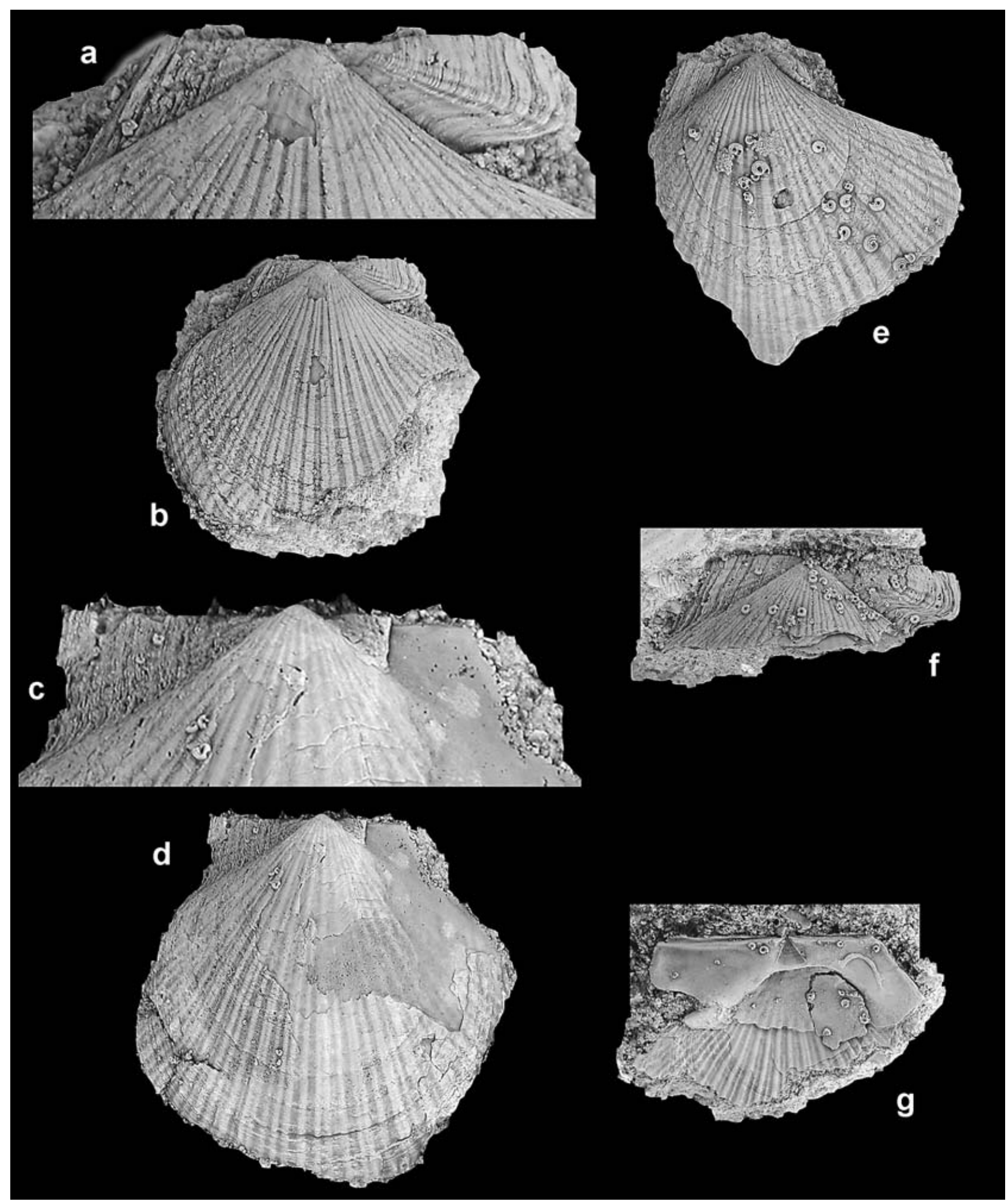

Fig. 3. Austrochlamys heardensis Fleming from locality shown on Fig. 1. a.b. right valve exterior, CPC37048. a. x 2.2, b. natural size, c. d. left valve exterior, CPC37049, c. x 2.2, d. natural size. e. left valve exterior, CPC37050, x 1.2. f. detail of hinge area, exterior right valve, CPC37051, natural size. g. Interior of hinge area of right valve to show resilifer, CPC37052, x 1.5. e-g also illustrate small serpulid (Spirorbis) worm tubes. 
including both right and left valves. Although most shells are badly broken, many complete specimens or those illustrating key features have been extracted by hammer and chisel, and cleaned using an engraving tool. Some 30-40 useful specimens were thus obtained. Almost all are right valves but one essentially complete left valve and some fragments of the umbonal region of left valves were recovered. The description of the left valve is based on the single almost complete valve which has both specimen and the external mould; the complete specimen is decorticated in the postero-dorsal area so that details of the surface of the posterior auricle are not preserved.

An attempt was made to determine the age of the fossil shell based on the degree of aspartic acid racemization, measured as a ratio of $\mathrm{D}$ - and $\mathrm{L}$-amino acid isomers (higher $\mathrm{D} / \mathrm{L}$ values correspond with increasing age). Full details of the analytical method followed are provided elsewhere (Murray-Wallace 1993). Measurement of aspartic acid enantiomers was based on gas chromatography of N-pentafluorpropionol D, L-aspartic acid 2-propyl esters.

Siliceous microfossils in a siltstone clast were identified with an Olympus microscope from strewn slides mounted with Norland optical adhesive (Refractive index $=1.56$ ). A list of species was collated by systematically scanning nine slides at low magnification (600x) and high magnification (1000x) for identification. The Southern Ocean Zonation of Harwood \& Maruyama (1992), revised to the Berggren et al. (1995) timescale (in Shipboard Scientific Party 2001) has been applied. The age range of some species was also determined from their occurrence in Southern Ocean ODP Site 1165 (Bohaty \& Whitehead, unpublished data).

Figured specimens and others are housed in the Commonwealth Palaeontological Collection at Geoscience Australia in Canberra. The original rock sample is curated at the Albany Residency Museum, Albany, Western Australia as specimen WAM 04.35.

\section{Depositional setting}

\section{Sedimentology}

The sample consists of a well-sorted, very coarse, grey volcaniclastic sandstone of basaltic fragments but with sporadic large clasts to about $8 \mathrm{~cm}$ diameter; most is in the coarse sand fraction. Thin section examination shows that the grains are dominantly of angular fragments but some are well rounded. Grains consist of vesicular and massive basalt (some with flow texture), vesicular volcanic glass with vesicles either empty or filled. Many grains are of angular fresh pyroxene, but such grains are not visible in the basalt fragments. The few phenocrysts in the basalt are of fresh plagioclase. A small clast of grey mudstone was recovered. The rock is cemented by fine, but not micritic, calcite which is a thin film on grains, and also fills some vesicles. Fine zeolite crystals are well preserved in vesicles and between basalt clasts. There are abundant disarticulated and broken specimens of $A$. heardensis to a length of $65 \mathrm{~mm}$. Other material seems to be very dominantly of the bivalve molluscs, often broken but of grain size much coarser than sand. Some molluses have attached serpulids (Spirorbis) and bryozoans, and others are burrowed.

\section{Accompanying biota}

The biota in the sediment is very highly dominated by Austrochlamys heardensis. Two specimens of a poorly preserved, incomplete (no dentition seen) thick-shelled (to $\sim 3 \mathrm{~mm}$ ) bivalve were also recovered. They are closely related to Lima watersi Marwick from the Tongaporutuan (Late Miocene) of New Zealand. The lack of dentition and the effects of the heavily bored shell hinder identification. Shells have small serpulids (Spirorbis sp.) or poorly preserved and unidentifiable bryozoans on both inner and outer surfaces. There are rare, very poorly preserved internal moulds of gastropods and a single, well preserved, articulated terebratulid brachiopod $8 \mathrm{~mm}$ long. A few sponge spicules were seen in the fine fraction. No foraminifera were found.

\section{Taphonomy}

Like Fleming's material, the surface has many small specimens of Spirorbis, 1-1.5 mm in diameter, attached. In addition, some specimens are deeply burrowed by worms, and calcareous worm-tubes are common. Encrusting bryozoans are present but are rare and poorly preserved. It is likely that these are post-death features because the small serpulids occur on both outside and inside the shell (Fig. 3e-g).

An apparent anomaly in this species is the preponderance of right valves in the sample studied. Fleming's (1957) collection was only of right valves and there are some 20 right valves for every left valve recovered in the sample studied. Jonkers (1998a, 1998b) and Speden (1962) figured only right valves of $A$. anderssoni and Birkenmajer \& Gadzicki (1986) illustrated right valves of A. gazdzickii Jonkers (as A. anderssoni). Where are the left valves? Fletcher's (1938) description of 'Chlamys' mawsoni from a solitary left valve also then seems an example of reverse anomaly. Part of a possible explanation may lie in the predation on scallops by seastars as the left valve is the uppermost in the living position and thus subject to attack (and breakage) from above. Jonkers (2003) also refers to the preponderance of right valves and predicted that left valves are likely to be thinner and thus more subject to breakage. Material studied here suggests that there is little difference in shell thickness between the two valves; both are relatively thin - 0.8-1.0 mm. Only after a complete left valve was recovered in this study was it realized that some fragments are of left valves. Fletcher (1938) refers to the left valve of ' $C$ '. mawsoni being thin, the situation here. 


\section{Environment of deposition}

All features of the sediment attest to a high energy, shallow water, fully marine environment of deposition close to a source of volcanic debris. Depth was near wave base, subject to considerable current activity which winnowed most fine debris, biogenic or detrital, and may be the cause of breakage of many of the valves. Cementation by carbonate was a later feature aided by high porosity of the sediment.

\section{Stratigraphy}

The rock containing the bivalves has yielded no foraminifera or calcareous nanoplankton to act as age control, consistent with the concept of their having been winnowed out in a high energy environment. Initially the bivalve suggested correlation with the Drygalski Formation of Late Miocene age (Quilty et al. unpublished data), on Heard Island and the lithology is similar to that described for sedimentary facies within the Drygalski Formation. The 63-125 $\mu \mathrm{m}$ fraction contains a few broken sponge spicules. The sample predates the Pliocene/Pleistocene extinction of pectinid molluscs described by Berkman \& Prentice (1996), following Petuch (1995).

\section{Biostratigraphy - diatoms}

The volcaniclastic sandstone yielded a single clast, approximately $1 \mathrm{~cm}^{3}$ in volume, of a medium grey, fine, uniform, non-bedded siltstone with sponge spicules and diatoms. The clast predates, or is almost coeval with, deposition of the sandstone, and provides a maximum age limit to the sandstone and its fossil content.

Sparse diatom and sponge spicule fragments comprise $<1 \%$ of the sediment (by visual estimate). The most common planktonic diatoms are Coscinodiscus spp., in particular extant $C$. marginatus Ehrenberg with a first occurrence (FO) datum of $\sim 16.5 \mathrm{Ma}$ at ODP Site 1165 . The apices of coarsely aereolated Rhizosolenia hebetata form hiemalis Grun, which has a FO 13.2 Ma at Site 1165, were also common. However, the age of the sample is constrained to $<3.2 \mathrm{Ma}$ from the presence of one fragment of Fragilariopsis kerguelensis (O’Meara). Rarer fragments of Azpeitia tabularis (Grunow) and Actinocyclus sp. are present, as well as fragments of Thalassionema, Trichotoxon or Thalassiothrix. Rare fragments of benthic diatoms Isthmia sp. and Gramatophora sp. suggest close proximity to a shallow marine environment. Sponge spicule fragments are also common and are accessory to diatoms in shallow waters, such as around the Antarctic continental shelf (Dunbar et al. 1989).

\section{Chemostratigraphy}

Given the low present day water temperature at the sample site of $2.2^{\circ} \mathrm{C}$, and as a corollary, the low diagenetic temperature history that the shells are likely to have experienced, the fast racemizing amino acid, aspartic acid, was selected for analysis. Aspartic acid provides the greatest potential for resolving the age for regions characterized by low diagenetic temperature histories. Slower racemizing amino acids, in contrast, may present difficulties in the chromatographic baseline resolution of D-amino acids due to their potentially very low degree of racemization.

The mean $\mathrm{D} / \mathrm{L}$ ratio for aspartic acid (total acid hydrolysate) for the shell material is $0.352 \pm 0.005(n=3)$. A numeric age for these shells was determined based on a model of apparent parabolic racemization kinetics (Mitterer \& Kriausakul 1989). The age calculation was calibrated based on the degree of racemization in the fossil cockle Katelysia rhytiphora $\left(\mathrm{D} / \mathrm{L}_{\mathrm{ASP}}=0.80\right.$ : Murray-Wallace \& Kimber 1989) from the Jandakot Beds of the Perth Basin, Western Australia, which based on micropalaeontological evidence straddles the Pliocene/Pleistocene transition (Mallett 1982). As racemization rates are known approximately to double for every $5^{\circ} \mathrm{C}$ change in temperature, an appropriate correction was made to account for the contrasting rates of racemization between the sample and the calibration sites, based on the difference in modern temperatures $\left(\Delta \mathrm{T}^{\circ} \mathrm{C} \approx 16^{\circ} \mathrm{C}\right)$. An aspartic acid $\mathrm{D} / \mathrm{L}$ value of 0.04 , representative of modern shells and accounting for the small amount of racemization induced during the laboratory hydrolysis reaction $\left(110^{\circ} \mathrm{C}\right.$ for 22 hours in $\left.8 \mathrm{~mol} \mathrm{HCl}\right)$ was also incorporated in the age calculation.

On the basis of the above, a minimum age for the shell is $2.20 \pm 0.33 \mathrm{Ma}$. The uncertainty term accounts for a $1^{\circ} \mathrm{C}$ uncertainty in diagenetic temperature. The age represents a minimum value in view of the paucity of information available on the nature of racemization kinetics in these shells.

At $700 \mathrm{~m}$ near the locality, current water temperature is $2.2^{\circ} \mathrm{C}$, and salinity $34.59 \%$ but the temperature and salinity history of the site are subjects of speculation. If the Antarctic Polar Frontal Zone has been south of the site, it is possible that temperature in the past has been higher. Many temperature histories are possible.

In summary, the age appears to be Late Pliocene, 3.62-2 Ma. If the extinction of Austrochlamys from Antarctica at $2.5 \mathrm{Ma}$, referred to by Jonkers (2003) extended to the Heard Island region, the age may be restricted to 3.62-2.5 Ma.

\section{Regional geological setting}

The sample was obtained from a small south-east promontory on the north-east-south-west oriented, highly dissected south-east scarplike margin of a plateau that supports both Heard Island and the McDonald Islands. The plateau may coincide with the 'Heard massif' (term used but not defined) of Ramsay et al. (1986) and is $230 \mathrm{~km}$ 
(NE-SW) by $140 \mathrm{~km}$ (NW-SE). This margin contrasts strongly with the gentle, non-dissected north-west slope of the plateau $140 \mathrm{~km}$ to the north-west of Heard Island where the $400 \mathrm{~m}$ isobath has segments markedly parallel to the plateau's southern boundary. On a high-resolution bathymetric chart (Australian Antarctic Division 1995), this margin continues to the east-north-east and marks the southern margin of Shell Bank. It was also well marked by the 500 fathom isobath in the compilation by Houtz et al. (1977). Another geomorphological expression of this feature is that it appears to displace sinistrally by $50 \mathrm{~km}$ or more, that part of Kerguelen Plateau to its south, and is expressed on the seafloor of the Australia-Antarctic Basin by isobaths parallel to it. The position of the scarp is well marked on the free air gravity field (67) as illustrated by Frey et al.(2000) and also on the SEASAT gravity data in Ramsay et al. (1986, fig. 5). A magnetic anomaly occurs on the northeastern end of seismic line RS-13 (between shot points 86-2200 and 87-0200 - fig. 14 of Ramsay et al. 1986) coinciding with the position of the scarp. Ramsay et al. (1986) noted that 'The sedimentary section probably thins over basement at the latitude of Heard Island ... before thickening again to more than $1.5 \mathrm{~s}$ south of the island.' The scarp also seems related to the position of a transform fault illustrated by Munschy et al. (1992, fig. 4). Borissova et al. (2002) figured seismic line 047-013 (line RS-13 of Ramsay et al. 1986) and showed that there is a dramatic thickening of early Tertiary sediment south of the scarp, in turn suggesting that the scarp is early Tertiary in age and thus related to the time of separation of Kerguelen Plateau from Broken ridge. The scarp then would appear to have been formed as part of transform faulting at this time.

A parallel and apparently similar feature to the southern scarp margin of the 'Heard massif' marks the northern flank of Banzare Bank, and this also coincides with the position of a transform fault in the compilation by Munschy et al. (1992) and the southern end of the nearby $77^{\circ}$ Graben.

McDonald Island (currently active volcanically) marks the southern end of a series of seamounts (Aurora Bank, Coral Bank, and an apparently unnamed seamount centred on $\left.51^{\circ} 15^{\prime} \mathrm{S}, 70^{\circ} 45^{\prime} \mathrm{E}\right)$ perpendicular to the southern scarp, that may mark a hotspot trace. No such seamount series leads to Heard Island.

North of this margin, the sole recorded example of Cretaceous sediment is on the sea floor north of Shell Bank $\left(51^{\circ} 25.3^{\prime} \mathrm{S}, \quad 7^{\circ} 34.52^{\prime} \mathrm{E} ; \quad\right.$ Quilty 2002$)$ where Late

Table I. Depths to top of Cretaceous sediment on southern Kerguelen Plateau.

\begin{tabular}{lc}
\hline Sample Site & Depth (mbsf) \\
\hline ODP 747 & 1827 \\
ODP 748 & 1708 \\
ODP 750 & 2386 \\
ODP 1138A & 1632 \\
Eltanin E54-7 & 430 \\
\hline
\end{tabular}

Maastrichtian sediment occurs on the seafloor in $420 \mathrm{~m}$ water depth. South of this margin, the Cretaceous/Tertiary boundary is significantly deeper (Table I). This represents a general difference of $>1000 \mathrm{~m}$.

Cretaceous sediments have not been recorded north of this margin except for the sample dredged during fishing operations. This may be simply an outcrop of an upturned older sequence as depicted by Munschy \& Schlich (1987). Even if this is true, Cretaceous sediments north of the margin occur at shallow sea floor depths, and south of it well below the sea floor, suggesting that, as is apparent topographically, the line represents a relative fall by Southern Kerguelen Plateau of well over $1000 \mathrm{~m}$.

The $200 \mathrm{~m}$ isobath on both northern and southern sides of the Heard Plateau is much more highly dissected than deeper isobaths, consistent with subaerial exposure during glacial maxima. The southern margin is more highly dissected than the northern and contains two significant submarine canyon systems (Fig. 1), perhaps draining sediment to a depocentre to the south-west. The age of this submergence is indeterminate with the information available, but probably postdates the deposition of the Chlamys rich sediments, to account for shallow deposition, submergence to current depth, and erosion.

\section{Lithostratigraphic correlation}

The locality lies in Central Kerguelen Plateau (Barron et al. 1989, Wise et al. 1989, Coffin et al. 2000, Quilty et al. unpublished data) which has basement (basalt) ages of mid Cretaceous (approximately $100 \mathrm{Ma}$ ). Nothing is known through ocean drilling between Heard Island and Îles Kerguelen. The closest drill sites are Ocean Drilling Program (ODP) Site 737 about $250 \mathrm{~km}$ north-east of Pike Bank and Site 1138, south-east of Heard Island (Fig. 1).

At Site $737\left(50^{\circ} 13.67^{\prime} \mathrm{S}, 7^{\circ} 01.97^{\prime} \mathrm{E} ; 564 \mathrm{~m}\right.$ water depth) drilling sampled a $1.5 \mathrm{~m}$ thick Quaternary section (Unit I) of black, mixed glauconitic sand and diatom ooze which contains some pumice and pebbles to $25 \mathrm{~mm}$. It is younger than the sample studied. Unit I overlies Unit II, an apparently continuous Early Pliocene/Late Miocene sequence (1.5-240.1 $\mathrm{m}$ below sea floor [mbsf]; 3.4-8.2 Ma), apparently unconformably. Unit III (240.1-306.6 mbsf) is Late and Middle Miocene in age and overlies conformably Unit IV (306.3-321.1 mbsf; Middle Miocene). The dominant components of Units II, III and IV are diatoms and calcareous nanofossils, but several horizons are marked by abundant volcanic glass or sand. Apart from glauconite, the main detrital components in Unit II seem to be "a suite of volcanic components consisting of blocky, sand-sized, usually fresh - but with some altered - subhedral plagioclase, altered brown palagonite volcanic glass, some fresh glass, and small quantities of yellow-green, elongate, subhedral pyroxene" (Barron et al. 1989). It is possible, but unlikely, that the uppermost parts of Unit II are equivalent 
to the material studied here and that the new sample accumulated while the unconformity between Units I and II was formed.

Site $1138\left(53^{\circ} 33.1^{\prime} \mathrm{S}, 75^{\circ} 58.5^{\prime} \mathrm{E}\right.$; $1141 \mathrm{~m}$ water depth) is the closest ODP site to the dredged sample and lies $115 \mathrm{~km}$ to its south-east. Unit I (1-112 mbsf; Late Miocene to Late Pleistocene) is diatomaceous clay with foraminifera and contains some ash bands, but generally is quite different lithologically from the dredged sample. The interval 58-80 mbsf appears to be approximately equivalent to the age of the sample studied here and Bohaty et al. (2003) postulated that the source of volcanic rocks was near Heard Island.

The Drygalski Formation is the source of the type material of Austrochlamys heardensis. Fleming, on the basis of comparison with other Southern Hemisphere chlamyds, favoured a Pliocene age while not ruling out the possibility of 'upper Miocene' or interglacial Pleistocene. The age of the Drygalski Formation on Heard Island is under study at present to refine the results obtained by Quilty et al. (1983) who determined an age of Late Miocene/Early Pliocene. Jonkers (2003) quotes a date of slightly younger than $9.4 \pm$ $2.4 \mathrm{Ma}$ (Late Miocene) for a basalt clast of Drygalski Formation in West Bay on the southern side of Laurens Peninsula (Fig. 2).

Volcanism has been active in the area throughout this time but the source may not have been constant.

\section{Systematic palaeontology}

\author{
Phylum MOLLUSCA \\ Class BIVALVIA Linné, 1758 \\ Family PECTINIDAE Wilkes, 1810 \\ Subfamily PECTININAE Wilkes, 1810 \\ Tribe AUSTROCHLAMYDINI Jonkers, 2003 \\ Genus Austrochlamys Jonkers, 2003 \\ Austrochlamys heardensis (Fleming, 1957)
}

Fig. $3 \mathrm{a}-\mathrm{g}$

Chlamys (Zygochlamys) heardensis Fleming, 1957, p. 16, text-fig. 1D, pl. 1, figs. 1,3.

Chlamys patagonica heardensis Fleming. Beu 1985, p. 7. Austrochlamys heardensis (Fleming). Jonkers, 2003, p. 66, pl. 12, fig. e.

\section{Description}

Right valve (from Fleming 1957). 'Right valve large, solid, slightly inflated, circular in outline, height and length equal. Hinge line straight, anterior ears [auricles] slightly longer than posterior. Beak angle about $115^{\circ}$.

Sculpture of strong flatly rounded radial ribs, mostly grouped in twos, owing to the gemination of each rib by the appearance of a groove on its summit. Fifteen ribs at $10 \mathrm{~mm}$. from the beak already include one or two which have arisen by development of a median groove. At greater diameters, more and more ribs subdivide at irregular intervals and become as strong as undivided ribs so that at $40 \mathrm{~mm}$ from the beak there are about 9 double ribs and 15 undivided ribs, a total of about 33 . At the ventral margin, about 40 ribs are mostly grouped in pairs, with interspaces between each pair about the width of a rib, those between members of a pair about half as wide. A few ribs at the margin bear faint grooves showing the beginning of a secondary splitting. Concentric sculpture of strong imbricate incremental lamellae, free distally, about $2.5 \mathrm{~mm}^{-1}$. The paratypes agree remarkably well with the holotype in the arrangement and number of ribs, as far as can be determined from incomplete specimens.

Posterior ear [auricle] obtusely angled, sculptured by strong incremental lamellae crossing 4-5 faint radial ribs. Anterior ear elongate, narrow, with a few (2-3) obsolete radial ribs. Byssal notch and fasciole not preserved in holotype. Sub-margins obscurely preserved but apparently well defined. In a paratype (F15299) the byssal notch is seen to be shallow.'

Resilifer triangular (Fig. 3g)

Left valve (new): Valve large, virtually circular, $66 \mathrm{~mm}$ high, $64 \mathrm{~mm}$ (perhaps plus 1-2 mm) long. Inflation very similar to that of the right valve, approximately $15 \mathrm{~mm}$ from the plane of commissure at this size. Hinge line straight, $38 \mathrm{~mm}$ long; anterior auricle slightly longer $(17 \mathrm{~mm})$ than posterior $(14 \mathrm{~mm})$. Beak angle $115^{\circ}$.

Ribs similar to those of the right valve. About 14 ribs at $10 \mathrm{~mm}$ from the umbo, one or two already divided. Mature region of the disc (at about $40 \mathrm{~mm}$ from umbo) has 35-40 ribs commonly grouped in pairs but usually with an undivided rib between pairs. Double ribs arise by development of median groove. About 9-10 pairs at this stage. Growth lamellae about $3 \mathrm{~mm}^{-1}$ in the central part of the disc.

Anterior auricle slightly obtuse angled $\left(95^{\circ}\right)$. Crossed by fine, clear, incremental lamellae, with 4-5 fine ribs radiating from the umbo and concentrated towards the ventral part of the auricle. Outline of posterior auricle clear but surface detail not preserved; decidedly obtuse angled at about $120^{\circ}$; a mirror image of the posterior auricle of the right valve. Neither a byssal nor auricular sulcus seen.

Both left and right valves are thin $(0.8-1 \mathrm{~mm})$ and of similar thickness.

\section{Discussion}

Fleming (1957) had only the holotype (right valve partly decorticated), another specimen of the beak area and three other right valves. The new material provides a much larger population and there is variability not possible for Fleming (1957) to see. While most right valves recovered agree precisely with his description (supporting his statement of remarkable agreement of paratypes with the holotype), 
there is some variation. For example, one specimen has a beak angle of only $90^{\circ}$ but the anterior and posterior margins of the disc are gently concave so that the margins ultimately diverge at $120^{\circ}$ and there are more and finer posterior ribs than on the holotype. Another has only the posterior margin concave.

On most right valves, the main body of the disc has only double ribs as obvious on the holotype, but in the left valve described, these commonly are separated by an undivided rib arising close to the umbo by intercalation.

\section{Comparison with similar species}

Fleming (1957) referred this species to Chlamys (Zygochlamys) Ihering 1907. Beu (1985) argued that Zygochlamys was inappropriate and avoided its use, placing this species as a subspecies of Chlamys patagonica. Lamprell \& Whitehead (1992) followed Beu in regarding Zygochlamys as inappropriate. Waller (1991) showed that Chlamys sensu stricto is a Northern Hemisphere genus and that the South America-New Zealand group should be referred generically to Zygochlamys. Beu \& Darragh (2001) stated that they regarded Chlamys delicatula (Hutton) as correctly assigned to Zygochlamys, accepted Zygochlamys as of genus rank, and believed that Zygochlamys is a widespread Southern Hemisphere genus. Jonkers (2003) proposed that Zygochlamys should be restricted, on phylogenetic grounds, to species around South America and erected the genus Austrochlamys to include six species including $A$. anderssoni and $A$. heardensis. He also erected the Tribe Austrochlamydini to include only this genus. This approach is followed here. Jonkers (2003) compared $A$. heardensis with $A$. anderssoni and with $A$. natans walosseki Jonkers.

\section{Austrochlamys anderssoni (Hennig, 1911).}

Fleming (1957) compared A. heardensis with many other species and it is clear that the closest known relative is A. anderssoni. Jonkers (1998a, 1998b) reviewed the stratigraphic occurrence of late Cenozoic pectinids from Antarctica (including the islands off the Antarctic Peninsula, but not from the sub-Antarctic) and listed in some detail the fauna of Late Pliocene sediments on Cockburn Island. Both papers contained illustrations of the right valves of $A$. anderssoni.

The two species are very similar in size and have very similar ear outlines. Beak angle is clearly greater in A. heardensis $\left(115^{\circ}\right)$ than in $A$. anderssoni $\left(90^{\circ}\right)$. The posterior auricle seems identical in both species but possible differences between the anterior auricles are not discernible from published descriptions and illustrations. A. anderssoni has a slightly concave anterior margin to its disc and this feature also appears on some right valves of $A$. heardensis.

Other than in beak angle, the major clear difference in the right valves is the features of the radial ribs in the adult.
Fleming's (1957) description refers to the 'beginning of a secondary splitting' as indicated by the presence of 'faint grooves'. The feature is characteristic of the species. There are hints of the faint groove in some $A$. anderssoni but the feature is much better developed in $A$. heardensis. In the right valve of $A$. anderssoni, from Jonkers' figures, there appear to be two ribs that are slightly more robust and prominent than the others. One is virtually perpendicular to the hinge line, and the other anterior to it by $20-25^{\circ}$. There are 6-7 uniform-sized ribs between, with slightly narrower inter-rib spaces. This feature is not evident in A. heardensis where routine pairing of ribs is characteristic. The auricles of the left valve are identical with those of $A$. anderssoni as illustrated by Fleming (1957) and Jonkers (1998a, 1998b) drawing out, once again, the similarity of the two species.

Austrochlamys anderssoni and A. heardensis are the only two species of this genus to be known from several localities and in rocks of several ages, and are closely related. Both are Late Miocene-Late Pliocene. Both species occur south of the Antarctic Polar Frontal Zone. This is in contrast with the occurrence of 'Chlamys' mawsoni which is now, and probably has been for a long time, north of the Polar Frontal Zone.

\section{'Chlamys' mawsoni Fletcher, 1938.}

'Chlamys' mawsoni was described from a single left valve for which most detail (other than of the auricles) was obscured by other molluscan shell material (Fletcher 1938). Fletcher's illustrations show a little detail of the ribs at the ventral margin of the shell. Fleming (1957) apparently 'excavated' the shell and re-illustrated it. There are about 60 ribs in ' $C$ '. (Z.) mawsoni and only about 40 on $A$. heardensis and this expresses itself in the former on the disc near the umbo as finer, more numerous ribs. Fletcher refers to ribs as 'occasionally duplex', suggesting some similarity in this regard with both $A$. heardensis and $A$. anderssoni. The hingeline of ' $C$ '. mawsoni is relatively shorter than that of $A$. heardensis and the anterior auricle of ' $C$ '. mawsoni has a greater development of radial 'riblets'. The umbonal angle of ' $C$ '. mawsoni is about $90^{\circ}$, less than the $115^{\circ}$ of $A$. heardensis. The height/length ratio in ' $C$ '. mawsoni is a little higher than in A. heardensis. Jonkers (2003) pointed out that the taxonomic position of this species is unclear and left it questionably in 'Chlamys'.

\section{Conclusions}

The left valve of Austrochlamys heardensis Fleming is now known and described and the species is compared and contrasted with $A$. anderssoni (Hennig) from Cockburn Island, the taxonomically most similar species, and with ' $C$ '. mawsoni Fletcher of Îles Kerguelen, the geographically closest. The variation of the right valve is documented. The preponderance of right valves in the collection may be due to the left valve being more subject to breakage during 
predation and current activity.

The material studied was deposited in an area of high current activity near wave base, in a fully marine environment. If the sample was in situ, the location has subsided some $500 \mathrm{~m}$ since deposition, at a rate of about 160-200 m m. $\mathrm{y}^{-1}$.

The characteristics of the site and its rocks lead to speculation on the tectonic significance of the scarp south of Heard Island. It appears to mark the position of a transform fault with left lateral displacement of some $50 \mathrm{~km}$ and vertical displacement of $>1 \mathrm{~km}$. It probably originated during transform faulting associated with the separation of Kerguelen Plateau from Broken Ridge in the early Tertiary. Other parallel features on Kerguelen Plateau, such as that at the northern end of Banzare Bank, may have a similar origin.

\section{Acknowledgements}

We have great pleasure in acknowledging again the help of Mr R. Williams of the Australian Antarctic Division, Kingston, Tasmania, and of Captain H. Stefansson of FV Austral Champion who recognized the possible value of the specimen. Ms V. Milne, Director of the Albany Residency Museum, co-operated in every step associated with the study and Mr D. Smith of the same institution helped greatly in obtaining material to work on. The Australian Antarctic Division kindly provided the base for the locality map, and its Multimedia Unit (especially the late Mr W. Papps again) aided plate development. Dr J. Laurie and $\mathrm{Mr}$ C. Thun of Geoscience Australia, Canberra helped with the imaging of the specimens. The authors are very grateful for valuable referees' comments by Dr H.A. Jonkers and Dr O. Mandic.

\section{References}

Australian Antarctic Division 1995. Heard Island bathymetric map. IMW part sheet numbers SM-42 SM-43 SN-42 SN-43.

Barron, J., Larsen, B. et al. 1989. Proceedings of the Ocean Drilling Program, Initial Reports, 119, 942 pp.

Berggren, W.A., Kent, D.V., Swisher III, C.C. \& Aubury, M.-P. 1995. A revised Cenozoic geochronology and chronostratigraphy. In BERGGREN, W.A., Kent, D.V., Aubury, M.P. \& Hardenbol, J.A., eds. Geochronology, time scales and global stratigraphic correlation. Society for Sedimentary Geology, Special Publication, No. 54, 129-212.

Berkman, P.A. \& Prentice, M.C. 1996. Pliocene extinction of Antarctic pectinid mollusks. Science, 271, 1606-1607.

BEU, A.G. 1985. Pleistocene Chlamys patagonica delicatula (Bivalvia: Pectinidae) off southeastern Tasmania, and history of its species group in the Southern Ocean. In LindsAY, J.M., ed. Stratigraphy, palaeontology, malacology. Department of Mines and Energy South Australia, Special Publication, 5, 1-11.

Beu, A.G. \& Darragh, T.A. 2001. Revision of southern Australian Cenozoic fossil Pectinidae (Mollusca: Bivalvia). Proceedings of the Royal Society of Victoria, 113, 1-205.
Birkenmajer, K. \& Gazdzicki, A. 1986. Oligocene age of the Pecten Conglomerate on King George Island, West Antarctica. Bulletin of the Polish Academy of Sciences, Earth Sciences, 34, 219-226.

Bohaty, S.M., Wise JR, S.W., Duncan, R.A., Moore, C.L. \& Wallace, P.J. 2003. Neogene diatom biostratigraphy, tephra stratigraphy, and chronology of ODP Hole 1138A, Kerguelen Plateau. Proceedings of the Ocean Drilling Program, Scientific Results, 183, 1-53.

Borissova, I., Moore, A., Sayers, J., Parums, R., Coffin, M.F. \& SYMONDS, P.A. 2002. Geological framework of the Kerguelen Plateau and adjacent ocean basins. Geoscience Australia, Record, 2002/05, $120 \mathrm{pp}$.

Coffin, M.F., Frey, A.F., Wallace, P.J. et al. 2000. Proceedings of the Ocean Drilling Program, Initial Reports, 183, 1-101.

Dunbar, R.B., Leventer, A.R. \& Stockton, W.L. 1989. Biogenic sedimentation in McMurdo Sound, Antarctica. Marine Geology, 85 , $155-179$.

Fleming, C.A. 1957. A new species of fossil Chlamys from the Drygalski Agglomerate of Heard Island, Indian Ocean. Journal of the Geological Society of Australia, 4, 13-19.

FLETCHER, H.O. 1938. Marine Tertiary fossils and a description of a recent Mytilus from Kerguelen Island. B.A.N.Z. Antarctic Research Expedition 1929-1931, Reports, Series A, 2(6), 101-116.

Frey, F.A., Coffin, M.F., Wallace, P.J., Weis, D., Zhao, X., Wise JR, S.W., Wähnert, V., Teagle, D.A.H., Saccocia, P.J., Reusch, D.N., Pringle, M.S., Nicolaysen, K.E., Neal, C.R., Müller, R.D., Moore, C.L., Mahoney, J.J., Keszthelyi, L., Inokuchi, H., Duncan, R.A., Delius, H., Damuth, J.E., Damasceno, D., Coxall, H.K., Borre, M.K., Boehm, F., Barling, J., Arndt, N.T. \& Antretter, M. 2000. Origin and evolution of a submarine large igneous province: the Kerguelen Plateau and Broken Ridge, southern Indian Ocean. Earth and Planetary Science Letters, 176, 73-89.

Harwood, D.M. \& Maruyama, T. 1992. Middle Eocene to Pleistocene diatom biostratigraphy of Southern Ocean sediments from the Kerguelen Plateau. Proceedings of the Ocean Drilling Program, Scientific Results, 120, 683-733.

Hennig, A. 1911. Le conglomérat Pleistocène à Pecten de l'Île Cockburn. Wissenschaftliche Ergebnisse der Schwedisch Südpolar-Expedition 1901-1903, 3(10), 1-72.

Houtz, R.E., Hayes, D.E. \& MarkL, R.G. 1977. Kerguelen Plateau bathymetry, sediment distribution and crustal structure. Marine Geology, 25, 95-130.

Jonkers, H.A. 1998a. Stratigraphy of Antarctic late Cenozoic pectinidbearing deposits. Antarctic Science, 10, 161-170.

Jonkers, H.A. 1998b. The Cockburn Island Formation: Late Pliocene interglacial sedimentation in the James Ross Basin, northern Antarctic Peninsula. Newsletters in Stratigraphy, 36, 63-76.

Jonkers, H.A. 2003. Late Cenozoic-Recent Pectinidae (Mollusca: Bivalvia) of the Southern Ocean and neighbouring regions. Monographs of Marine Mollusca, 5, 1-125.

LAmprell, K. \& WhiteheAd, T. 1992. Bivalves of Australia, Vol. 1. Bathurst: Crawford House Press, 182 pp.

LinNAEus, C. 1758. Systema Naturae per Regna Tria Naturae [...] editio decima, reformata. Regnum animale, vol. 1. Stockholm: Laurentii Salvi.

Mallett, C.W. 1982. Late Pliocene planktonic foraminifera from subsurface shell beds, Jandakot, near Perth, Western Australia. Search, 13, 35-36.

MitTerer, R.M. \& Kriausakul, N. 1989. Calculation of amino acid racemization ages based on apparent parabolic kinetics. Quaternary Science Reviews, 8, 353-357.

Munschy, M., Dyment, J., Boulanger, M.O., Boulanger, D., Tissot, J.D., Schlich, R., Rotstein, Y. \& Coffin, M.F. 1992. Breakup and seafloor spreading between Kerguelen Plateau-Labuan Basin and the Broken Ridge-Diamantina Zone. Proceedings of the Ocean Drilling Program, Scientific Results, 120, 931-944. 
Munschy, M. \& Schlich, R. 1987. Structure and evolution of the Kerguelen-Heard Plateau (Indian Ocean) deduced from seismic stratigraphy studies. Marine Geology, 76, 131-152.

Murray-Wallace, C.V. 1993. A review of the application of the amino acid racemisation reaction to archaeological dating. The Artefact, 16, 19-26.

Murray-Wallace, C.V. \& Kimber, R.W.L. 1989. Quaternary marine aminostratigraphy: Perth Basin, Western Australia. Australian Journal of Earth Sciences, 36, 553-568.

Petuch, E.J. 1995. Molluscan diversity in the Late Neogene of Florida: evidence for a two-staged mass extinction. Science, 270, 275-277.

QuiLty, P.G. 2002. Late Cretaceous foraminifera from a dredge and from ODP Site 1138, Kerguelen Plateau, southern Indian Ocean. Proceedings of the Ocean Drilling Program, Scientific Results, 183, 1-28.

QuILTY, P.G. in press. Heard Island and the McDonald Islands: built on the Kerguelen Plateau foundation. In Green, K. \& Woehler, E.J., eds. Heard Island; sentinel of the Southern Ocean. Sydney: Surrey Beattie

Quilty, P.G., Shafik, S., McMinn, A., Brady, H. \& Clarke, I. 1983. Microfossil evidence for the age and environment of deposition of sediments of Heard and McDonald Islands. In OLIVER, R.L., JAMES, P.R. \& JAgO, J.B., eds. Antarctic earth science. Canberra: Australian Academy of Science, 636-639.

Quilty, P.G. \& Wheller, G. 2000. Heard Island and the McDonald Islands: a window into the Kerguelen Plateau. Papers and Proceedings of the Royal Society of Tasmania, 133 (2), 1-12.
Ramsay, D.C., Colwell, J.B., Coffin, M.F., Davies, H.L., Hill, P.J., Johnston, N.A., Pigram, C.J. \& StagG, H.M.J. 1986. Rig Seismic research cruise 2: Kerguelen Plateau - initial report. Report, Bureau of Mineral Resources, Geology and Geophysics, 270, 1-41.

SCHLICH, R. \& WiSE JR, S.W. 1992. The geologic and tectonic evolution of the Kerguelen Plateau: an introduction to the scientific results of Leg 120. In Wise JR, S.W., Schlich, R. et al. Proceedings of the Ocean Drilling Program, Scientific Results, 120, 5-30.

Shipboard Scientific Party. 2001. Proceedings of the Ocean Drilling Program, Initial Reports, 188, 1-65.

SPEDEN, I.G. 1962. Fossiliferous Quaternary marine deposits in the McMurdo Sound region, Antarctica. New Zealand Journal of Geology and Geophysics, 5, 746-777.

StePhenson, P.J. 1964. Some geological observations on Heard Island. In AdIE, R.J., ed. Antarctic geology. Amsterdam: North Holland Publishing, 14-24.

WALLER, T.R. 1991. Evolutionary relationships among commercial scallops (Mollusca: Bivalvia: Pectinidae). In SHumway, S.E., ed. Scallops: biology, ecology and aquaculture. Amsterdam: Elsevier, 1-73.

WILKES, J. 1810. Conchology. Encyclopaedia Londinensis, or, Universal Dictionary of Arts, Sciences, and Literature. London: Wilkes, 14-41.

WiSE JR, S.W., Schlich, R., et al. 1989. Proceedings of the Ocean Drilling Program, Initial Results, 120, 648 pp. 